\title{
Effect of breeds on semen characteristics of aged bulls in the Indonesian National Artificial Insemination Center
}

\author{
I. Novianti $^{1)}$, B. Purwantara ${ }^{3)}$, E. Herwijanti ${ }^{4)}$, C.D. Nugraha ${ }^{1)}$, R.F. Putri ${ }^{1)}$, A. Furqon ${ }^{1)}$, W.A. \\ Septian $^{1)}$, S. Rahayu ${ }^{2)}$, V.M.A. Nurgiartiningsih ${ }^{1)}$, S.Suyadi ${ }^{1{ }^{*}}$ \\ 1) Faculty of Animal Science, Universitas Brawijaya, Jl. Veteran, Ketawanggede, Kec. \\ Lowokwaru, Kota Malang, Jawa Timur Indonesia 65145 \\ ${ }^{2)}$ Faculty of Mathematics and Natural Sciences, Universitas Brawijaya, Jl. Veteran, \\ Ketawanggede, Kec. Lowokwaru, Kota Malang, Jawa Timur Indonesia 65145 \\ ${ }^{3)}$ Faculty of Veterinary Medicine, IPB University, Jl. Agatis, Kampus IPB Darmaga, Bogor, \\ Indonesia, 16680 \\ 4) National Artificial Insemination Center of Singosari, Singosari, Malang, East Java, \\ Indonesia, 65153
}

Submitted: 17 April 2020, Accepted: 01 August 2020

\begin{abstract}
Madura and Bali cattle are two of Indonesian indigenous breeds. One possible method to increase their productivity is through artificial insemination (AI) using frozen semen. This study conducted at the Singosari National Artificial Insemination Center, East Java, Indonesia, to evaluate the semen characteristics of different bull breeds ranging in age from 7 to 10 years and to provide useful recommendations regarding the efficacy of older cattle. A total of 2016 ejaculation data recorded from Indonesian indigenous cattle (Madura and Bali bulls) and Bos taurus bulls (Simmental) were used in this study to analyze semen volume, sperm motility, and sperm concentration. Results revealed differences in semen volume, sperm motility, and sperm concentration among bull breeds $(\mathrm{p}<0.05)$. Simmental bulls have the highest semen volume $(\mathrm{p}<0.05)$ compared with Bali and Madura bulls. Base on sperm motility, Bali bulls showed the highest average value $(p<0.05)$ compared with Simmental and Madura bulls. Sperm concentration was the highest $(\mathrm{p}<0.05)$ among Bali bulls compared with Simmental and Madura bulls. Another important finding was that the average semen volume, sperm motility, and sperm concentration of older bulls fulfilled the standard criteria established for frozen semen processing. Therefore, it would be possible to improve the performance of these breeds through artificial insemination using frozen semen of Madura and Bali bulls, which can be more widely distributed to farmers to increase their herd productivity. This study also indicates that Indonesian indigenous bulls have superior semen characteristics than Simmental bulls.
\end{abstract}

Keywords: Bull; Semen characteristics; Madura cattle; Bali cattle; Simmental cattle

*Corresponding Author: suyadi@ub.ac.id 


\section{INTRODUCTION}

Indonesian indigenous cattle are known to have good adaptability to a wet tropical climate that is characterized by various parasites, diseases, and low-quality feed (Sutarno, 2015). However, local Indonesian cattle have lower productivity than exotic breeds such as Simmental cattle. Bali and Madura cattle are examples of the Indonesian indigenous cattle that have a prominent role in the livestock industry in Indonesia. Bali cattle are a domesticated Banteng species (Bibos banteng), whereas Madura cattle comes from crossbreeding Zebu and Bali cattle (Kikkawa et al., 2003).

Bali cattle represent $27 \%$ of the total cattle population in Indonesia. The phenotypic characteristics of Bali cattle have been reported to be different from those of Bos taurus and B. indicus (Talib et al., 2003). Bali cattle have several characteristics, including a reddish-brown coat, white coat from the hindquarters to the belly, as well as and the hooves to just above the hocks. In bulls, the reddish color darkens. Also, Bali cattle have a prominent economic role as they achieve higher prices per kilogram live weight than other local breeds (Dwyanto, 2002)

Madura cattle are brick-red or brownish-red in color with a white coat on the back, belly, and rump. Madura cattle have small horns that have an upward curve (Sutarno et al., 2015). Madura cattle run fast so that it can be used as racing bulls ("karapan" as the local name), and those with an excellent body appearance/performance can be used as show cattle ("sonok" as the local name). Bulls that do not belong to either category are used as common beef cattle. In general, the Madura breed has high value as a source of income when slaughtered and as a source of prestige as "karapan" and "sonok". Madura cattle also supports in the farming sector as draught animals and producers of fertilizer for the Madurese people. Given the vital role of Madura and Bali cattle, their productivity can be better by improving the performance of the bulls. One possible method is through artificial insemination (AI). As a part of their mission, AI centers have a prominent role in selecting superior bulls to provide quality frozen semen for farmers. Since frozen cattle semen is widely and regularly distributed, the centers have to produce an amount that is sufficient and of good quality.

Singosari National Artificial Insemination Centre (SNAIC), East Java, is one of two National Artificial Insemination Centers (NAICs) in Indonesia. It maintains $B$. sondaicus, B. indicus, and B. taurus breeds, which are a mixture of young and aged bulls. It is known that in human, age is affecting semen quality (Carreira et a.l, 2017) and it has also detected in rats (Zubkova et al., 2006). In large domestic cattle like cattle, there is a tendency to use young cattle in order to obtain good reproduction. The study investigates the semen characteristics of aged bulls (7-10 years old) and also to provide useful recommendations concerning the efficacy of older cattle. Breed is also one of the factors that affects the characteristics of bull semen. The second objective was to compare the semen characteristics of 2016 ejaculation data recorded from indigenous bulls (Madura and Bali) and B. taurus bulls (Simmental) ranging in age from 7 to 10 years. Factors such as age, semen volume, sperm motility, and sperm concentration were analyzed.

\section{MATERIALS AND METHODS}

This study happened at the NAIC at Singosari, Malang, East Java, Indonesia. This facility distributes frozen semen to the majority of regions in Indonesia and other ASEAN countries. The study used 2016 ejaculates from 5 Madura, 14 Bali, and 11 Simmental bulls in 2017. The age of the bulls ranged between 7 and 10 years. The animals were maintained individually in the barn. Simmental bulls'feeds were $16 \mathrm{~kg}$ forage, $3 \mathrm{~kg}$ silage, $4 \mathrm{~kg}$ concentrate, $4 \mathrm{~kg}$ hay, and $0.05 \mathrm{~kg}$ commercial mineral per 
day. Each Madura and Bali cattle uses $10 \mathrm{~kg}$ forage, $2.5 \mathrm{~kg}$ silage, $2.5 \mathrm{~kg}$ concentrate, 3 $\mathrm{kg}$ hay, and $0.05 \mathrm{~kg}$ commercial mineral per day as feed.

The analysis uses variables age, semen volume, sperm motility, and sperm concentration in this study. Collecting semen uses an artificial vagina for each bull. The volume was measured using a scaled vial, and the sperm motility was assessed under a light microscope at 400x magnification, while the concentration evaluation uses a spectrophotometer (Nugraha et al., 2019).

The analyizing data uses a generalized linear model, one-way ANOVA $(\mathrm{P}<0.05)$, using the SPSS 24 software. Duncan's multiple range test (DMRT) was used to determine any significant differences.

\section{RESULTS AND DISCUSSION Effect of bull breed on semen volume}

The results of the effect of bull breed on semen volume description is in Table 1, wherein a highly significant effect of breed on semen volume was detected $(\mathrm{P}<0.01)$. Further statistical analyses revealed that the average semen volume of Simmental bulls $(6.635 \pm 2.341 \mathrm{~mL})$ was significantly higher than those of Madura $(5.734 \pm 1.740 \mathrm{~mL})$ and Bali (5.628 $\pm 1.815 \mathrm{~mL})$ bulls.
However, statistically no difference between the semen volumes of Madura and Bali bulls.Breed had a highly significant effect on semen volume, which is consistent with the studies of Isnaini et al., (2019), Koivisto et al., (2009), and Field et al., (1979), who also reported a similar result. This significant effect could be associated with the differences in scrotal circumference (SC) among different breeds (Siddiqui et al., 2008). SC and semen volume have a positive correlation, as confirmed in a previous study conducted by Ejaz et al. (2013). Also, semen volume increases by bull age, and it might due to the increased size of SC.

Regarding the difference between the semen volume of Indonesian indigenous cattle (Madura and Bali) and that of $B$. taurus bulls (Simmental), we found that the volume of the Simmental bull semen was the highest. This result was not surprising as it has been reported that $B$. taurus cattle generally have a larger SC than $B$. indicus cattle (Brito et al., 2004), which contributes to bigger testicles. Consequently, there are more seminiferous tubules, which thus increases the semen volume (Nugraha et al., 2019). Testes thermoregulation and hormonal regulation were other factors affecting semen volume (Indriastuti et al., 2020).

Table 1. Effect of bull breed on semen volume

\begin{tabular}{cccccc}
\hline Breed & Ejaculations & Min $(\mathrm{mL})$ & Max $(\mathrm{mL})$ & Mean \pm SD $(\mathrm{mL})$ & P-value \\
\hline Madura & 287 & 0.6 & 10.2 & $5.734 \pm 1740^{\mathrm{a}}$ & \\
Bali & 781 & 1 & 13.4 & $5.628 \pm 1.815^{\mathrm{a}}$ & 0.000 \\
Simmental & 948 & 0.5 & 14 & $6.635 \pm 2.341^{\mathrm{b}}$ & \\
\hline
\end{tabular}

Different superscript letters show a significant difference $(\mathrm{P}<0.05)$

\section{Effect of bull breed on sperm motility}

Sperm motility is one of the significant characteristics of semen affecting bull fertility. We found a significant effect of breed on sperm motility. Furthermore, Simmental bulls had the lowest sperm motility compared with indigenous bulls (Bali and Madura) (Table 2). Statistical analysis revealed that Simmental bulls had the lowest average sperm motility of $65.959 \% \pm 4.45 \%$, whereas Bali bulls had the highest average sperm motility of $67.766 \% \pm 4.263 \%$. This finding is in accordance with the Ashrafzadeh (2013), who found that Malaysian local cattle had higher sperm motility than crossbreeds. A possible explanation for this might be the differences in bovine's seminal plasma among breeds.

Seminal plasma is a mixture of biochemical components that are secreted from the testes, epididymis, and accessory 
sex glands. It provides a medium that supports sperm during ejaculation and migration through the female reproductive tract, leading to fertilization. Some previous studies have investigated the bovine seminal plasma proteome of $B$. taurus, B. indicus, and crossbreeds between $B$. taurus and $B$. indicus bulls and detected different protein structures and levels (Assumpção et al., 2005; Kelly et al., 2006; Druart et al., 2013; Ashrafzadeh et al., 2013).

Concerning sperm motility, the different proteins involved in the structure of the flagella and energy utilization might contribute to the differences in motility between breeds (Ashrafzadeh et al., 2013). In Nellore bulls, motility negatively correlated with age, which shows the older the cattle, the lower the motility (Carreira et al., 2017). However, Madura and Bali cattle showed a different trend. 8 and 12 years old Madura bull had higher motility (66.76 \pm 1.92 and $64.41 \pm 1.13$, respectively) compare to 4 years old Madura Bull (41.62 22.86) (Briliansyah et al., 2020). Meanwhile, young Bali bulls had lower motility $(56.7 \pm 15.6)$ than ten years old Bali

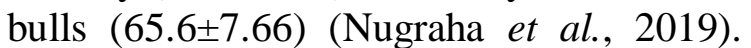
Those results showed that different breeds might have a different trend of motility.

Table 2. Effect of bull breed on sperm motility

\begin{tabular}{lccccc}
\hline \multicolumn{1}{c}{ Breed } & Ejaculations & Min $(\%)$ & Max $(\%)$ & Mean \pm SD $(\%)$ & P-value \\
\hline Madura & 287 & 55 & 75 & $66.934 \pm 4.823^{\mathrm{b}}$ & \\
Bali & 781 & 55 & 80 & $67.766 \pm 4.263^{\mathrm{c}}$ & 0.000 \\
Simmental & 948 & 69 & 75 & $65.959 \pm 4.45^{\mathrm{a}}$ & \\
\hline
\end{tabular}

Different superscript letters show a significant difference $(\mathrm{P}<0.05)$

Table 3. Effect of bull breed on sperm concentration

\begin{tabular}{lccccc}
\hline Breed & Ejaculations & $\begin{array}{c}\text { Min }\left(\times 10^{6}\right. \\
\text { sperms } / \mathrm{mL})\end{array}$ & $\begin{array}{c}\text { Max }\left(\times 10^{6}\right. \\
\text { sperms } / \mathrm{mL})\end{array}$ & $\begin{array}{c}\text { Mean } \pm \text { SD }\left(\times 10^{6}\right. \\
\text { sperms } / \mathrm{mL})\end{array}$ & P-value \\
\hline Madura & 287 & 77 & 1933 & $797.526 \pm 347.872^{\mathrm{a}}$ & \\
Bali & 781 & 256 & 1877 & $1044.178 \pm 279.190^{\mathrm{c}}$ & 0.000 \\
Simmental & 948 & 106 & 2241 & $876.558 \pm 382.252^{\mathrm{b}}$ & \\
\hline
\end{tabular}

Different superscript letters show a significant difference $(\mathrm{P}<0.05)$

\section{Effect of bull breed on sperm concentration}

Sperm concentration is the number of spermatozoa contained in one ejaculation and thus determines the success rate of mating. In this study, the effect of the breed was highly significant (Table 3). Sperm concentration was different between breeds. Bali bulls had the highest semen concentration $\left(1044.178 \pm 279.190 \times 10^{6}\right.$ sperms/mL), followed by Madura (797.526 $\pm 347.872 \times 10^{6}$ sperms $/ \mathrm{mL}$ ) and Simmental $\left(876.558 \pm 382.252 \times 10^{6}\right.$ sperms $\left./ \mathrm{mL}\right)$ bulls .

This result had different patterns concerning semen volumes. However, this finding is in contrast to a previous study conducted by Isnaini et al. (2019), who found that Simmental cattle had a higher sperm concentration than Bali cattle.
Nevertheless, this difference might be the result of the different ages of bulls in the study.Base on cattle's age, some studies examined the effect of age on bull concentration. Younger Madura, Bali, and Simmental bulls had higher sperm concentration compared to the older ones (Briliansyah et al., 2020; Nugraha et al., 2019; Watl et al., 2006). Results show that the sperm concentration of aged Madura, Bali, and Simmental bulls fulfills the requirement for frozen semen processing.

The low sperm concentration of Simmental cattle found in this study was consistent with that reported by Berry et al., (2019), who indicated a negative genetic correlation $(-0.44)$ between semen volume and sperm concentration. Therefore, it could be predicted that cattle with higher semen 
volumes have lower sperm concentrations. Bull semen volume contains only $10 \%$ sperm, and the rest $(90 \%)$ is the seminal plasma (Setchell, 2014). Higher semen volume means that there are more seminal plasma and less sperm. Moreover, since semen quality affected by breed, the different breed might also cause sperm concentration differences (Morrell et al.,2017).

\section{CONCLUSION}

This study compared the effect of breed on the characteristics of semen of the aged bulls, including Madura, Bali, and Simmental bulls. Results revealed highly significant effects of breed on semen volume, sperm motility, and sperm concentration, particularly for older bulls. Moreover, the semen samples of older bulls were found to fulfill the requirement for frozen semen processing. In general, it appears that Indonesian indigenous bulls tend to have better semen quality than $B$. taurus (Simmental).

Altogether, the finding suggests that Indonesian indigenous cattle have superior semen characteristics than B. Taurus. Therefore, it would be possible to improve their performance through artificial insemination. Besides, frozen semen samples of Madura and Bali bulls could be more widely distributed to farmers to increase their herd productivity.

\section{ACKNOWLEDGMENTS}

The authors of this joint article are grateful to USAID, which has funded and supported this study through the Sustainable Higher Education Research Alliances (SHERA) Program Center for Collaborative Research Animal Biotechnology and Coral Reef Fisheries (CCR ANBIOCORE) No 03/IT3.2/KsP/2018-UB-01.

Additionally, Special thanks are for the Team of Singosari Artificial National Insemination Center (SNAIC) for providing semen production and sperm quality data. Acknowledgment also for the help provided by Dr. Alan McGee and Maren Behrend
(Massey University, New Zealand) in the preparation of this article.

\section{REFERENCES}

Ahmad, E., Ahmad, N., \& Naseer, Z. (2014). Association of scrotal circumference with sperm production and semen quality in sahiwal bulls. Pakistan Veterinary Journal, 34(2), 265-266.

Ashrafzadeh, A., Nathan, S., \& Karsani, S. (2013). Comparative Analysis of Mafriwal (Bos taurus $\times$ Bos indicus) and Kedah Kelantan (Bos indicus) Sperm Proteome Identifies Sperm Proteins Potentially Responsible for Higher Fertility in a Tropical Climate. International Journal of Molecular Sciences, 14(8), 15860-15877. https:// doi.org/10.3390/ijms140815860

Assumpcao, T., Fontes, W., Sousa, M., \& Ricart, C. (2005). Proteome analysis of nelore bull (Bos taurus indicus) seminal plasma. Protein \& Peptide Letters, 12(8), 813-817. https://doi. org/10.2174/0929866054864292

Berry, D. P., Eivers, B., Dunne, G., \& McParland, S. (2019). Genetics of bull semen characteristics in a multi-breed cattle population. Theriogenology, 123, 202-208. https://doi.org/10.10 16/j.theriogenology.2018.10.006

Brito, L. F., Silva, A. E. D., Barbosa, R. T., \& Kastelic, J. P. (2004). Testicular thermoregulation in Bos indicus, crossbred and Bos taurus bulls: relationship with scrotal, testicular vascular cone and testicular morphology, and effects on semen quality and sperm production. Theriogenology, 61(2-3), 511-528. https://doi.org/10.1016/S009 3-691X(03)0023 1-0

Carreira, J. T., Trevizan, J. T., Carvalho, I. R., Kipper, B., Rodrigues, L. H., Silva, C., Koivisto, M. B. (2017). Does sperm quality and DNA integrity differ in cryopreserved semen samples from young, adult, and aged Nellore bulls? Basic and Clinical Andrology, 27(1), 12. https://doi.org/10.1186/s12 610-017-0056-9 
Druart, X., Rickard, J. P., Mactier, S., Kohnke, P. L., Kershaw-Young, C. M., Bathgate, R., de Graaf, S. P. (2013). Proteomic characterization and cross species comparison of mammalian seminal plasma. Journal of Proteomics, 91, 13-22. https:// doi.org/10.1016/j.jprot.2013.05.029

Fuerst-Waltl, B., Schwarzenbacher, H., Perner, C., \& Sölkner, J. (2006). Effects of age and environmental factors on semen production and semen quality of Austrian Simmental bulls. Animal Reproduction Science, 95(1-2), 27-37. https://doi.org/10.10 16/j.anireprosci.2005.09.002

Indriastuti, R., Ulum, M. F., Arifiantini, R. I., Memili, E., \& Purwantara, B. (2020). Relationship among body weight, scrotal circumference and sperm quantity of Bali Bulls in Baturiti Artificial Insemination Center. IOP Conference Series: Earth and Environmental Science, 478, 012004. https://doi.org/10.1088/17551315/478/1/012004

Isnaini, N., Wahjuningsih, S., Ma'ruf, A., \& Witayanto, D. A. (2019). Effects of age and breed on semen quality of beef bull sires in an indonesian artificial insemination center. Livestock Research for Rural Development, 31(5).

Kelly, V. C., Kuy, S., Palmer, D. J., Xu, Z., Davis, S. R., \& Cooper, G. J. (2006). Characterization of bovine seminal plasma by proteomics. PROTEOMICS, 6(21), 5826-5833. https://doi.org/10. 1002/pmic.200500830

Kikkawa, Y., Takada, T., Nomura, K., Namikawa, T., Yonekawa, H., \& Amano, T. (2003). Phylogenies using mtDNA and SRY provide evidence for male-mediated introgression in Asian domestic cattle. Animal Genetics, 34(2), 96-101. https://doi.org/10.104 6/j.1365-2052.2003.00956.x

Koivisto, M., Costa, M., Perri, S., \& Vicente, W. (2009). The effect of season on semen characteristics and freezability in Bos indicus and Bos taurus Bulls in the Southeastern Region of Brazil. Reproduction in Domestic Animals, 44(4), 587-592. https://doi.org/10.1111/j.1439-0531.2 008.01023.x

Kurniawan, M. B., Isnaini, N., \& Kholifah, Y. (2020). Fresh semen quantity and quality of Madura Bulls in relation to age. Russian Journal of Agricultural and Socio-Economic Sciences, 98(2), 12-15. https://doi.org/10.18551/rjoas .2020-02.02

Morrell, J. M., Nongbua, T., Valeanu, S., Lima Verde, I., Lundstedt-Enkel, K., Edman, A., \& Johannisson, A. (2017). Sperm quality variables as indicators of bull fertility may be breed dependent. Animal Reproduction Science, 185, 42-52. https://doi.org/ 10.1016/j.anireprosci.2017.08.001

Nugraha, C. D., Herwijanti, E., Novianti, I., Furqon, A., Septian, W. A., Busono, W., \& Suyadi, S. (2019). Correlations between age of Bali bull and semen production at National Artificial Insemination Center, Singosari Indonesia. Journal of the Indonesian Tropical Animal Agriculture, 44(3), 258-260. https://doi.org/10.14710/jita a.44.3.258-265

Setchell, B. (2014). Semen and its Constituents. Animal Andrology: Theories and Applications, 3(1).

Siddiqui, M., Bhattacharjee, J., Das, Z., Islam, M., Islam, M., Haque, M., Shamsuddin, M. (2007). Crossbred bull selection for bigger scrotum and shorter age at puberty with potentials for better quality semen. Reproduction in Domestic Animals, 43(1), 74-79. https://doi.org/10.1111/j.1439-0531.2 007.00857.x

Sutarno, \& Setyawan, A. D. (2015, June 27). Review: Genetic diversity of local and exotic cattle and their crossbreeding impact on the quality of Indonesian cattle. Biodiversitas. Society for Indonesian Biodiversity. https://doi. org/10.13057/biodiv/d160230

Talib, C., Entwistle, K., Siregar, A., 
Budiarti-Turner, S., \& Lindsay, D. (2003). Survey of population and production dynamics of Bali Cattle and existing breeding programs in Indonesia. In K. Entwistle \& D. R. Lindsay (Eds.), Aciar Proceedings (pp. 3-9). Canberra: Australian Centre for International Agricultural Research.
Zubkova, E. V., \& Robaire, B. (2006). Effects of ageing on spermatozoal chromatin and its sensitivity to in vivo and in vitro oxidative challenge in the Brown Norway rat. Human Reproduction, 21(11), 2901-2910. https://doi.org/10.1093/humrep/del193 